\title{
Effect of Quality Products, Services and Brand on Customer Satisfaction at McDonald's
}

\section{Priyono lyon Priyono*}

Department of Management, University Pgri Adi Buana, Indonesia

${ }^{*}$ Corresponding author: Priyono IP, Department of Management, University Pgri Adi Buana, Surabaya, Jawa Timur, Indonesia, Tel: 06281216973515; E-mail: priyono.unu_sidoarjo@yahoo.com

Received date: February 10, 2017, Accepted date: April 24, 2017, Published date: May 01, 2017

Copyright: ( 2017 Priyono IP. This is an open-access article distributed under the terms of the Creative Commons Attribution License, which permits unrestricted use, distribution, and reproduction in any medium, provided the original author and source are credited.

\begin{abstract}
This study aims to identify and examine the influence of service quality, brand image and product quality on consumer purchasing decisions in Mc. Donald.

This research is explanatory. The number of samples was 96 respondents taken by purposive sampling method. Collecting data using questionnaires. Data were analyzed with the validity and reliability, cross tables, simple regression analysis, regression analysis, and hypothesis testing using the formula $\mathrm{t}$ arithmetic and $\mathrm{F}$ arithmetic.

The results showed the quality of service positive and significant influence on purchasing decisions, brand image positive and significant impact on purchasing decisions, product quality positive and significant impact on purchasing decisions, and service quality, brand image and product quality jointly influence positively and significantly the purchasing decision.
\end{abstract}

Keywords Effect of product quality; Brand; Service; Customer satisfaction

\section{Introduction}

Along with the changing times, the business world is currently experiencing very rapid progress. It can be seen from the many fast food restaurants have been opened by entrepreneurs in every major cities. With increasingly fierce competition, companies have desire to compete in attracting consumers. Fast food business has been progressing very rapidly, the market share of fast food restaurants Indonesia is quite large.

Services are increasingly becoming a larger portion of many organizations' regional, national, and global and is considered as a means to an income stream. knowledge-intensive business services today require reliable method of measurement, assessment and refinement (Spohrer and Maglio, 2008) quality of service is determined by calculating the difference between the two values where the result of better service quality in a small gap [1]. Johnston et al. conducted a comprehensive empirical experiments on dimensions of quality of service offered by Parasuraman et al. [2,3] in the top ten in the UK service organization. At first, they presented a list of 12 factors, and then with more research is done, they offered a list of 18 factors. In addition, many researchers have presented different models to test the quality of banking services, by inspiring of the model serve equal.

Kotler and Armstrong [4] states that the product quality is the ability of a product to perform its functions include durability, reliability, accuracy, ease of operation and repair as well as other valuable attributes. Proponents of this theory include researchers such as Yi [5]; Bloemer and Kasper [6]; Bastos and Gallego [7]; Chai et al. [8]. So far, few studies discusses the influence of customer service and product quality to customer satisfaction has been using the critical incident technique, Archer and Wesolowsky [9] to see how satisfaction with the quality of products and services simultaneously affect intention owners in the automotive industry [8]. In this case, Bastos and Gallego [7] provide evidence that the customer service quality directly affects customer satisfaction and the satisfaction of directly influencing positive behavioral intentions.

Brand image is presented according to Aaker overall brand formed from information and past experience to the brand. Brand easier for consumers to identify products or services in the level of consumer recognition. The creation of the impression of being one of the basic characteristics of the modern marketing orientation that is through giving more attention as well as the creation of a strong brand. The implications of making it the brand of a product creates an image of the product itself in the minds of consumers' minds and makes the underlying motivations for consumers to choose a product [10]. For that brand can be one of the factors that should be considered by consumers in making purchasing decisions.

Quality has been defined as fitness for use, or the extent to which a product is successfully serve the needs of consumers [11]. Customer service is one of the processes that organizations performing companies given the growing competition and to attract entrepreneurial opportunities to improve profitability and better access to markets and increase customer satisfaction and loyalty levels [12].

Despite the importance of quality of service, so far few studies have been done in this field in Iran, but many studies have been conducted outside Iran. At least 293 important articles were written from 1976 to 1995 on the quality of service. Meanwhile, if we consider the articles were quality of service is part of the article; this number will be 4000 article. Thus clearly show the importance of quality of service, and the attention of researchers for this topic [13]. 
To attract consumers in large numbers, the company has always demonstrated the superiority of the products owned and satisfying service its customers. That's because consumers always want the quality of the product in terms of taste, cleanliness and service. One fast-food restaurants from America which has spread in Indonesia, namely Mc Donald's. continues to innovate in its products to attract customers and compete in the business world.

\section{Research Methods}

\section{Population}

According Sugiyono [14] population is generalization region consisting of objects /subjects that have certain qualities and characteristics are set by investigators to be learned and then drawn conclusions. Thus the population in this study is that consumers in the Mc Donald's Palembang.

\section{Samples}

According Sugiyono (2012: 81) the sample is part of the number and characteristics possessed by the population. In determining the sample if the population is large and the amount is not known, according to the Primitive (1996: 34) used the formula: $n=Z^{2} / 4$ (Moe) ${ }^{2}$

Where: $n=$ number of samples, $Z=$ normal distribution rate at significance level of $5 \%=1.96$, Moe=Margin of Error, which is the maximum sampling error rate that can be tolerated or is desired. By using a margin of error of $10 \%$, the minimum number of samples that can be taken by:

$$
\mathrm{n}=1,96^{2} / 4(0,10)^{2}=96,04 \text { or } 96
$$

The sampling technique in this research is done by accidental sampling that is part of the technique of nonprobability sampling is a form of sampling by coincidence, that anyone who happened to meet with researchers and considered fit to be the source of the data will be sampled this study [15]. By what criteria do purchase at least three times in Mc Donald's Palembang.

\section{Variables operational research and definitions}

\section{Variables}

Quality Products $\left(\mathrm{X}_{1}\right)$

The respondent's perception about the quality of products $\mathrm{Mc}$ Donald's Palembang

Brand $\left(\mathrm{X}_{2}\right)$

Perceptions of respondents about the brand Mc Donald's.

Service $\left(\mathrm{X}_{3}\right)$

Perceptions of respondents would be of service received by customers for utilizing the services of

Mc Donald's Palembang.

Variable bound

Customer Satisfaction (Y)

Perceptions of respondents about consumer satisfaction with the services received by consumers for utilizing the services of $\mathrm{Mc}$ Donald's.

\section{Research instruments questionnaires}

According Sugiyono [15] questionnaire is a technique of data collection is done by giving a set of questions to respondents to answer the researchers used a Likert scale in Sugiyono [15] by calculating the weight of each question. That amount will then be used as study variable weights of respondents rated the following details:

Strongly agree by weight 5

Agreed by weight 4

Hesitation is weighted 3

Disagreeing is weighted 2

Strongly disagree is weighted 1

\section{Data analysis techniques}

\section{Testing Instrument research}

Uji validity and reliability: Validity and reliability questions were conducted to determine the research results are valid and reliable, the necessary instruments valid means of measuring instruments used to obtain data (measures) that valid. While reliable instrument is an instrument which, when used several times to measure the same object, will generate the same data. To test the validity and reliability of the instrument (questionnaire), the researchers used the help of a software program SPSS (Statistical Package for Social) version 20.0.

\section{Uji classical assumption}

Test multicollinearitas: Test multicollinieritas means between independent variables with each other independent variables in the regression model of a relationship nearly perfect or perfect relationship [16].

Test autokolerasi: Autocorrelation can be defined as the influence of variables performance model through an interval/happening correlation between her random tool [16]. To detect the symptoms of this autocorrelation can be used to test the Durbin Watson Test.

Test heterokedastisitas: This test aims to determine whether the regression model variants occur inequality of residual one observation to another observation remains then called and if different homokedastisitas called heterokedastisitas.

Normality test: This assumption test aims to test whether a regression model residuals of the regression equation has a normal distribution or not. A good regression model is to have a data distribution normal or nearly normal. According to Hasan and Iqbal [16] means for detecting normality is:

- If the data are spread around the diagonal line and follow the direction of the diagonal line regression models meet the assumptions of normality.

- If the data are spread far from the diagonal or does not pick following the direction of the diagonal line of the regression models do not meet the assumption of normality.

Data analysis using regression: Data obtained from the questionnaire will be analyzed using statistical methods Regression in aids in the SPSS program. Statistical methods were used to determine the relationship of the independent variables (Independent) and the dependent variable (Dependent), which aims to predict and estimate the value of the dependent variable in relation to the particular independent variable. Once the relationship between the two variables 
were observed in the form of a linear relationship, then the model (linear) can be formulated in general terms:

$$
\begin{aligned}
& \mathrm{Y}=\mathrm{a}+1 \cdot 1+2 \cdot 2+3 \cdot 3 \\
& \text { Hypothesis testing } \\
& \text { Simultaneous Test (Test F) }
\end{aligned}
$$

\section{Simultaneous Test (Test F)}

Testing is done through the test by comparing $\mathrm{f} \mathrm{F}_{-}$(arithmetic) (F_h) with $F_{-}$(table) (F_t) at a 0.05 . The hypothesis is accepted if the test results show (F_h $>F_{-} t$ ) or the price obtained $\mathrm{p}<0.05$.

\section{Data Analysis and Discussion}

\section{Multiple linear regression}

From the results of multiple linear regression analysis obtained by the magnitude of the constant and the magnitude of the regression coefficients for each variable is as follows:

$$
\mathrm{Y}=8,463+0,316 \mathrm{X}_{1}+0,142 \mathrm{X}_{2}+0,163 \mathrm{X}_{3}
$$

The results of the equation, it can be explained as follows:

- Constants $(\mathrm{a})=8.463$, showing the extent of consumer satisfaction, if the quality of products, brands and services at zero, then customer satisfaction will be at 8.463 units.

- The regression coefficient of 0.316 product quality, shows the influence of product quality to customer satisfaction, the regression coefficient is positive demonstrate unidirectional influence product quality to customer satisfaction, which means that every increase of one - unit of product quality will lead to increased customer satisfaction by 0,316 units.

- The regression coefficient of 0.142 brands, underlining the brand influence on consumer satisfaction, the regression coefficient is positive indicates the direction of the brand influence consumer satisfaction, which means that every increase of one - unit of the brand will lead to increased customer satisfaction by 0,142 units.

- The regression coefficient of service equal to 0.163 , showed the influence of service to customer satisfaction, the regression coefficient is positive indicates the direction of the service affects customer satisfaction, which means that every increase of one service unit will lead to increased customer satisfaction by 0.163 units.

- The correlation coefficient (R) of 0.635 ; shows that there is a strong relationship between the quality of products, brands and services with customer satisfaction.

- The coefficient of determination (R square) of 0.403 . This shows that the variable quality of products, brands and services provide variations or able to contribute to variable customer satisfaction by $40.3 \%$, while the remaining $59.7 \%$ is caused by other variables not included in the study.

\section{Discussion}

To test the hypothesis that "The quality of products, brands and services affects customer satisfaction at Mc Donald's Palembang" using the Test-F. Some steps are performed on the test- $f$ are as follows:

- If the value of Sig. $\leq 0.05$ Declined So Ho and Ha accepted. Which means that the hypothesis testing proved significantly.

- If the value of Sig. >0,05 Then Ho accepted and Ha Rejected. Which means unproven hypothesis testing significantly.
The test results obtained $\mathrm{F}$ count $\mathrm{F}=20.720$ with sig. 0,000 $(0,000 \leq 0.05)$, the Rejected Ho and Ha accepted. Which means that the hypothesis that "the quality of products, brands and services affects customer satisfaction at Mc Donald's Palembang" unacceptable significantly.

Based on statistical analysis shows that the "quality of products, brands and services affects customer satisfaction at Mc Donald's Palembang". This can be explained, in terms of products according to Kotler and Armstrong [4] is: "A product as anything that can be offered to a market for attention, acquisition, use or consumption and that might satisfy a want or need". This means that the product is everything that is offered to the market to get attention, purchased, used, and which can satisfy the desires or needs of consumers.

This means that the product - the product Mc. Donald's have quality products that can satisfy its customers, the product quality is the thing to get a major concern of the company or the manufacturer, because the quality of the products is closely related to issues of consumer satisfaction that is the purpose of marketing activities undertaken by a company. Each company must have a high level of quality in order to improve their businesses and maintain the position of its products in the market. With the satisfaction by the consumer, then the better the product position in the competition, because the more desirable, sought-after and requested by consumers. In terms of brands, Kotler (2003: 115) argues that the brand is a name, term, sign, symbol, or design, or a combination of the whole, which aims to identify the goods or services of a group of sellers and to differentiate their products from competitors.

This suggests the establishment of an emotional connection between consumers and Mc Donald's Palembang, so consumers will not easily switch to a competing brand that even though the competitor producing similar products is not likely to produce the same emotional bond.

In terms of services, According to Kotler [17] definition of service is any action or activity that can be offered by one party to another, in order to meet consumer needs and desires in order to achieve customer satisfaction in itself. Professionalism, alertness and speed of the employee as well as the facilities provided Mc Donald's Palembang in providing services make consumers feel satisfied.

\section{Conclusions and Recommendation}

\section{Conclusion}

Based upon the review and statistical analysis of the data obtained in order to test the hypothesis proposed in this study, the authors infer things that the quality of products, brands and services affects customer satisfaction at Mc Donald's Palembang, the F test results obtained F count $=20.720$ with sig. $0,000(0,000 \leq 0.05)$, the Rejected $\mathrm{Ho}$ and $\mathrm{Ha}$ accepted. Which means that the hypothesis that "the quality of products, brands and services affects customer satisfaction at Mc Donald's Palembang" unacceptable significantly.

\section{Suggestion}

Referring to the analysis of hypotheses and conclusions, the authors suggest that the quality of products, brands and services affects customer satisfaction at Mc Donald's Palembang, then you should Mc Donald's Palembang to maintain the quality of products, introduce brand Mc Donald's and improve service quality to the maximum in 
Citation: Priyono IP (2017) Effect of Quality Products, Services and Brand on Customer Satisfaction at McDonald's. J Glob Econ 5: 247. doi: $10.4172 / 2375-4389.1000247$

Page 4 of 4

order for consumers can get a sense of satisfaction on the quality of products, brands and services at Mc Donald's Palembang.

\section{References}

1. Landrum H, Prybutok VR, Kappelman LA, Zhang X (2008) Servcess: a parsimonious instrument to measure service quality and information system success. The Quality Management Journal 15: 17-25.

2. Parasuraman A, Berry LL, Zeithaml V (1985) A conceptual models of service quality and the implications for future research. Journal of Marketing Management 49: 41-51.

3. Parasuraman A, Zeithaml V, Berry L (1988) SERVQUAL: A multiple item scale for measuring customer perceptions of service quality. Journal of Retailing 64: 12-40.

4. Kotler P, Armstrong G (2008) Principles of Marketing.

5. Yi Y (1990) A critical review of consumer satisfaction.

6. Bloemer JMM, Kasper HDP (1995) The complex relationship between consumer satisfaction and brand loyalty. Journal of Economic Psychology 16: 311-329.

7. Bastos JAR, Gallego PM (2008) Pharmacies Customer Satisfaction and Loyalty: A Framework Analysis. Journal of Marketing.
8. Chai KH, Ding Y, Xing Y (2009) Spillovers Quality and Customer Satisfaction in the Mobile Phone Industry. Service Science 1: 93-106

9. Archer NP, Wesolowsky GO (1996) Consumer Response to Service and Product Quality: A Study of Motor Vehicle Owners. Journal of Operations Management 14: 103-118.

10. Aaker DA (1997) Brand Equity Management. Key Partners, Jakarta.

11. Beverly KK, Diane M, Strong, Richard YW (2002) Information Quality Benchmarks: Product and Service Performance. Communications of the ACM. 45: 184-192.

12. Calif DHS (1987) Waste audit study: Automotive repairs.

13. Philip G, Hazlett S (1997) The Measurement of service quality: a new p-c$\mathrm{p}$ attributes model. International Journal of Quality and Reliability Management 14: 260-286.

14. Sugiyono (2002) Metedologi Research Administration. Alfabeta, Bandung.

15. Sugiyono (2012) Quantitative and Qualitative Research Methods R \& D. Alfabeta, Jakarta.

16. Hasan M, Iqbal (2001) Basic-Basic Materials Statistics I (Descriptive Statistics). Earth Literacy, Jakarta.

17. Kotler P (2002) Marketing Management 2002. Erland, Jakarta. 